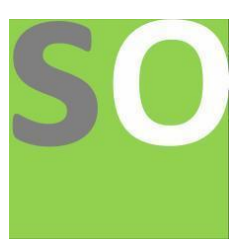

Article title: Rethinking the History of Peptic Ulcer Disease: from digital textual analysis to declining research programs

Authors: Bartosz Michal Radomski[1], Dunja Šešelja[2], Kim Naumann[3]

Affiliations: Ruhr University Bochum[1], Eindhoven University of Technology[2], LMU Munich[3]

Orcid ids: 0000-0003-4107-2425[1], 0000-0001-5679-5787[2]

Contact e-mail: bartosz.radomski1@gmail.com

License information: This work has been published open access under Creative Commons Attribution License http://creativecommons.org/licenses/by/4.0/, which permits unrestricted use, distribution, and reproduction in any medium, provided the original work is properly cited. Conditions, terms of use and publishing policy can be found at https://www.scienceopen.com/.

Preprint statement: This article is a preprint and has not been peer-reviewed, under consideration and submitted to ScienceOpen Preprints for open peer review.

DOI: 10.14293/S2199-1006.1.SOR-.PPAAH0L.v1

Preprint first posted online: 03 June 2020

Keywords: peptic ulcer disease, digital textual analysis, declining research program, history of medicine, etiology, pursuitworthiness, stress, vagotomy, Helicobacter pylori 


\title{
Rethinking the History of Peptic Ulcer Disease: from digital textual analysis to declining research programs
}

\author{
Bartosz Radomski ${ }^{1}$, Dunja Šešelja*2, and Kim Naumann ${ }^{3}$ \\ ${ }^{1}$ Institute for Philosophy II, Ruhr University Bochum \\ ${ }^{2}$ Philosophy $\& 3$ Ethics Group, TU Eindhoven \\ ${ }^{3}$ Munich Center for Mathematical Philosophy, LMU Munich
}

\begin{abstract}
The history of the research on peptic ulcer disease (PUD) is characterized by a premature abandonment of the bacterial hypothesis, which subsequently had its comeback, leading to the discovery of Helicobacter pylori - the major cause of the disease. In this paper we examine the received view on this case, according to which the primary reason for the abandonment of the bacterial hypothesis of PUD in the mid-twentieth century was a large-scale study by a prominent gastroenterologist Palmer, which suggested no bacteria could be found in the human stomach. To this end, we employ the method of digital textual analysis and study the literature on the etiology of PUD published in the decade prior to Palmer's article. Our findings suggest that the bacterial hypothesis of PUD had already been abandoned before the publication of Palmer's paper, which challenges the widely held view that his study played a crucial role in the development of this episode.

The paper makes two main contributions to the literature in integrated history and philosophy of science. First, we suggest that the received narrative on this historical episode, commonly used by philosophers, needs to be revised. Second, we introduce the notion of a 'declining research program' and argue for its importance as a unit of socio-epistemic analysis, especially in combination with normative assessments, such as pursuitworthiness of scientific theories.
\end{abstract}

Keywords: declining research program, peptic ulcer disease, Ed Palmer, digital textual analysis, pursuitworthiness.

${ }^{*}$ To contact the authors, please write to d.seselja@tue.nl and bartosz.radomski@rub.de. 


\section{Introduction}

The early 20th century research on peptic ulcer disease (PUD) is often mentioned as an example of scientific inquiry 'gone wrong' (e.g. Thagard, 2000, Solomon, 2001, Gilbert, 2000, Zollman, 2010, Wray, 2010, Miller, 2013, Šešelja and Straßer, 2014b). As most accounts of this case report, from the 19th century on there were two major rivaling hypotheses of the disease: the acidity hypothesis, according to which the disease is caused by an excessive acidity of the stomach, and the bacterial hypothesis, which stipulated bacteria as the primary cause of the disease. In the mid-20th century the bacterial hypothesis was abandoned, and the research on PUD and its treatment proceeded along the lines of the acidity research program. Nevertheless, in the 1980s Robin Warren and Barry Marshall discovered Helicobacter pylori, a bacterium which turned out to be the major cause of PUD. This discovery, for which Warren and Marshall received a Nobel Prize in Physiology or Medicine, led to the revival of the bacterial research program. Hence, the research on PUD was for three decades based on a worse of the two hypotheses.

According to the received view on the history of this episode (originating primarily in Marshall, 2002; Warren and Marshall, 1983'), the main reason for the abandonment of the bacterial hypothesis was a large-scale study by a prominent gastroenterologist, Ed Palmer (Palmer, 1954). Palmer examined 1,180 subjects, fifth of whom were healthy individuals, while the remainder of the group were patients with gastrointestinal complaints. The study showed no presence of bacteria in the gastric mucosa of the subjects. Nowadays we know that Palmer's study was deeply misleading as it was based on a method previously shown not to be suitable for detecting spiral bacteria (see ibid., Šešelja and Straßer, 2014b, Section 3). But if Palmer's study was indeed a game-changer in the research on PUD and the trigger for the abandonment of the bacterial hypothesis, how come nobody in the scientific community noticed potential problems with it? This is all the more surprising if we agree with Šešelja and Straßer (ibid.) that the bacterial hypothesis was worthy of pursuit in the 1950s, when it was allegedly abandoned.

This historical episode has often puzzled scholars working in the field of integrated history and philosophy of science. On the one hand, some have used it as an example of an inquiry in which everything was done by the book in the sense that each individual scientist had good reasons to abandon the bacterial hypothesis, and yet, the scientific community on the whole was

\footnotetext{
${ }^{1}$ See also Kidd and Modlin (1998a), Fukuda et al., 2002, Warren (2005, p. 18).
} 
sidetracked towards a false theory for a long period of time (Zollman, 2010, Kummerfeld and Zollman, 2016). As such, the PUD case appears to be a nice example of the individual and group rationality coming apart in the sense that rational choices by individual scientists do not sum up to an optimal inquiry at the level of the given community. On the other hand, as mentioned above, some have argued that the bacterial hypothesis was in fact worthy of pursuit at the time when it was given up on, which suggests that its abandonment was perhaps unwarranted (Šešelja and Straßer, 2014b). Given the puzzling course of events, this brings us to a question: what exactly went wrong, and who - if anyone - is to blame?

In this paper we aim to advance this debate by conducting a critical examination of the received view on PUD, according to which, the main reason for the abandonment of the bacterial hypothesis was Palmer's study. If the received narrative is correct, the abandonment of the bacterial hypothesis can be ascribed, for instance, to Palmer's influence, which swayed the entire medical community.

In order to uncover the details of this episode, we have used the method of digital textual analysis applied to the corpus of the English-language literature on PUD published throughout the decade prior to Palmer's study. Our aim was to examine whether the bacterial hypothesis of PUD belonged to what we will dub a declining research program already before Palmer's publication. By a declining research program we mean a larger theoretical unit which has had a significant decrease in active pursuit, relative to the rivaling theoretical frameworks in the given domain. ${ }^{2}$ The reason why this point is especially interesting is that, if confirmed, it would have important repercussions for philosophical discussions of this episode. In particular, the relevance of Palmer's study would be significantly reduced: even if his claims discouraged some scientists from pursuing the bacterial hypothesis, his study more likely played the role of being the final nail in the coffin of an already dying theory, than the actual game-changer, as commonly considered. Moreover, the above question - why was the bacterial hypothesis abandoned?would be much less puzzling, for it is not surprising that scientists abandon a declining research program. Instead, we would be confronted with different questions concerning socio-epistemic aspects of this case, such as: How come a research program that is worthy of pursuit starts to decline in popularity?

\footnotetext{
${ }^{2}$ While we are using Lakatos's term ('research program') to describe such larger research units (Lakatos, 1978), for the purposes of this paper this term could be substituted with related notions, such as Kuhn's paradigms (Kuhn, 1962 [1996]) or Laudan's research traditions (Laudan, 1977). Our notion of declining research programs should, however, not be conflated with Lakatos's degenerating research programs (see below Section 4).
} 
Does the given scientific community have an epistemic and moral duty to prevent such outcomes?

Here is how we will proceed. In Section 2 we give a historical overview of this case-study focusing on the question of why the bacterial research program of PUD got abandoned. In Section 3 we introduce the method of digital textual analysis, which we use to examine the historical claim that the bacterial research program was declining prior to the publication of Palmer's study. In Section 4 we discuss our results and the consequences thereof for the philosophical analysis of this episode and related socio-epistemological issues. Section 5 concludes the paper.

\section{Etiological theories of PUD}

In this section we provide a historical overview of the English-language research on PUD in the first half of the twentieth century, focusing on the question which factors, besides Palmer's paper, could have indirectly contributed to the abandonment of the bacterial hypothesis of PUD. To this end, we will primarily rely on secondary sources from history of medicine ${ }^{3}$ and first-hand testimonies from gastroenterologists who were working on PUD during the period of our interest, in Britain (Christie and Tansey, 2002) and worldwide (Warren, 2005). The secondary sources are useful for our purposes because they provide a broad social and historical context of the period beyond research labs. Moreover, they are comprehensive in the evidence used and written with the benefit of hindsight. The primary sources in turn give an insight into personal factors that led researchers away from the correct hypothesis.

Before turning to factors that are relevant in considering the downfall of the bacterial research program (or the 'germ theory of PUD'), we give a brief overview of different etiological theories of this disease researched in the first half of the twentieth century.

\footnotetext{
${ }^{3}$ Sources include: two articles on the history of abdominal illness in Britain during WWII by professional historians of medicine (Jones, 2012; Miller, 2010); an MD thesis in the history of medicine by Pollock (2014), which comprises a chapter on the history of etiological theories until 1960s; a historical overview of 'germ theory' research until Palmer's paper (Kidd and Modlin, 1998a); a critique of the biopsychosocial model with PUD as a case study (Davey Smith, 2005). The authors of the last two publications are medical practitioners and were included to represent two different interpretations of factors leading to the abandonment of the 'germ theory'. Moreover, we have included a recent case study on this topic, written in the field of integrated history and philosophy of science (Šešelja and Straßer, 2014b).
} 


\subsection{Theoretical pluralism}

While the research on PUD draws its origins from the late $16^{\text {th }}$ century, modern gastroenterological study of the disease started in the $19^{\text {th }}$ century. Two influential hypotheses of what causes PUD developed early on: on the one hand, the so-called acidity hypothesis, according to which the ulcer is caused by gastric juice corroding the stomach, and on the other hand, the bacterial hypothesis, which postulated bacteria as the cause of the disease (Kidd and Modlin, 1998b).

Moving on to the first half of the twentieth century, it is easy to notice a range of insufficiently corroborated etiological theories forming this research landscape (Miller, 2010, p. 105). Contrary to the commonly told story, the question of what causes PUD ceased to be a simple choice between the bacterial and the acidity theory. For instance, Pollock (2014, Chapter 3) distinguishes eight different factors that were at some point considered important in the genesis of peptic ulcers. These include not only germs and the acid, but also factors related to anatomical pathologies, inborn predispositions (such as e.g. an "ulcer personality type", see also Miller, 2010, p. 102), or psychological factors, such as stress (see also Jones, 2012, p. 13). What is more, gastroenterology was slow to develop as a specialized field, partly because there was no general agreement among surgeons and physicians on how to best treat digestive diseases (Miller, 2010, p. 105). Notably, however, the treatment of PUD-whether pharmacological or surgical - was mainly focused on reducing the acidity in the stomach (ibid., p. 105).

The research in the 1940s and the 1950s witnessed an increasing focus on the role of physiological and psychological factors on the development of PUD. The Lancet editorial from the end of the 1940s nicely illustrates this point: it posits that theories of peptic ulceration inevitably center around two possibilities: heightened erosive potency of gastric contents, or lowered antiacid resistance (Ætiology of Peptic Ulcer, 1949, p. 997). At the similar time, a number of editorials from The American Journal of Digestive Diseases ${ }^{4}$ emphasized in turn the psychological causes of PUD, such as anxiety and stress. The appearance of an ulcer was considered as a reduced capability of the body to prevent them, rather than as a result of increased external ulcerogenic factors (including bacteria).

Altogether, the research on PUD shifted away from a mono-causal and towards multi-causal approaches, and away from acidity as the sole etiological factor and towards the overall physiological balance in the stomach,

\footnotetext{
${ }^{4}$ For example Cornell, Lust, and Wyatt, 1944; "Editorial" 1954a; "Editorial" 1954b; "Peptic ulcer and "ordinary" anxiety" 1950.
} 
including the failure of its anti-ulcer mechanism (Connell, 1949). While in the beginning of the $20^{\text {th }}$ century the research in medicine was largely driven by a mono-causal perspective, closely related to the germ paradigm of disease (originating in the works of Koch and Pasteur), the situation started to change around the 1950s with the emergence of the chronic disease epidemiology (Carter, 2003; Šešelja and Straßer, 2014b). In case of the research on PUD though, the multi-causal perspective was perhaps notable already at an earlier point.

Some of the earliest indications that the idea of multiple causes was on the table comes from J. Shelton Horsley who commented that an ulcer may be produced by a combination of three factors: hyperacidity, toxic influences (possibly bacterial in nature), and the neurogenic (psychological) factors (Dragstedt, 1935, p. 579). After the WWII, the popularity of multi-causal theories increased. For instance, according to Kirsner and Palmer (1952, p. 615), "acid is indispensable" as a factor but "apparently not the only one". In a similar vein, Sullivan and McKell (1950, p. 14-20) introduced a "Theory of Multiple Etiology', taking a form of a simple mathematical ratio, where the ulcer was a result of imbalance in the ratio of the sum of contributing factors, e.g. personality, precipitating emotional situations, genetic factors, etc., and the overall resistance to ulcers. Relatively strong ulcer-inducing factors, or relatively weak resistance, could both lead to ulceration. Remarkably, while the presence of acid was deemed essential, the bacteria were not mentioned by Sullivan. Taken together, the multi-causal approach meant that the etiological search space was more nuanced and complex than a simple choice between an acid and a germ theory.

\subsection{Factors that played a role in the demise of the bacterial hypothesis}

We now take a closer look at different issues, beside Palmer's study, which could be explanatory of why the bacterial research program lost its popularity in the mid-twentieth century.

The role of hyperacidity As mentioned above, despite prolific arguments and the lack of agreement about the role of acid in ulceration, the acid theory seemed at the time to be the most fruitful hypothesis in terms of possible treatment (Christie and Tansey, 2002, p. 20). Therefore, the primary focus for treatment centered on regulating gastric secretion, which was reflected in a widely popular dictum: 'no acid, no ulcer', coined by Schwarz, 1910 (Bralow et al., 1950). 
The significance of acid as an etiological factor was in big part due to the work of Dragstedt (e.g. Dragstedt, 1935) who demonstrated that a high degree of acidity in the stomach was alone capable of causing ulcers. This led some scientists to consider hyper-acidity as the most immediate cause of ulcer (Rowland, 1937). As Pollock (2014, p. 93) comments, despite the lack of unanimity in the community, hyper-acidity became the main working hypothesis and the efforts towards an effective treatment were largely based on this assumption.

Vagotomy Another factor that played an important role in the decline of the bacterial research program is the success of a surgical procedure known as vagotomy. In order to treat ulcers, Dragstedt and Owens (1943) introduced a surgical method of cutting the vagus nerve, responsible for the acid secretion. Dragstedt established the viability of this procedure through a series of papers (Dragstedt, 1945; Dragstedt, Camp, and Fritz, 1949; Dragstedt et al., 1947; Dragstedt and Owens, 1943). Vagotomy appeared to work and until late 1970s it remained the most effective and reliable treatment for the condition, with comparatively fewest side-effects (Hobsley, 1994).$^{5}$

Problems in early bacteriological research Since the introduction of Koch's principles ${ }^{6}$ the major challenge for bacteriological theories was finding and identifying the disease-causing organism. Even though bacteria isolated from stomach ulcers were microscopically identified as early as in 1875, it was not clear which of them could play a part in the genesis of ulcers (Pollock, 2014, p. 85). Moreover, their reported frequency of occurrence in ulcerated stomachs was considerably lower than in other animals (Warren, 2005, p. 19). In the early $20^{\text {th }}$ century Turck $(1907,1908)$ examined the link between Bacillus coli and PUD but his findings were not successfully reproduced (Kidd and Modlin, 1998a, p. 8). At a similar time point, Edward Rosenow hypothesized that Streptococci were "commonly the original cause" of PUD (Rosenow and Sanford, 1915, p. 226) and attempted to induce ulcers with

\footnotetext{
${ }^{5}$ This is not to say that vagotomy was harmless: it still had a significant mortality rate. For example, Edwards et al., 1963 report the operative mortality rate of $2.7 \%$ (see also Ššelja and Straßer, 2014b, p. 437).

${ }^{6}$ In the second half of the $19^{\text {th }}$ century Koch presented a set of postulates for accepting the etiological role of bacteria: 1) The organism must be shown to be constantly present in characteristic form and arrangement in the diseased tissue; 2) the organism must be isolated and grown in pure culture; 3 ) the cultured organism must be shown to initiate and reproduce the disease when reinoculated into a healthy body; 4) the organism must be re-isolated from the experimentally infected organism (Thagard, 2000, p. 59).
} 
the aid of bacteria. Even though Rosenow's findings were influential and well-known (Pollock, 2014, p. 86), later researchers could not replicate the results using Rosenow's technique (Ivy, 1950, p. 271).

What's more, while Rosenow believed in the etiological role of bacteria in ulceration, he held that it was the bacteria in and around the mouth and away from the abdomen that were to blame. In short, he looked for PUD-related bacteria outside of the stomach. This view was a particular expression of a 'focal infection' theory, which posited that local sepsis in the teeth, tonsils, or sinuses, allowed a blood-borne spread of bacteria or toxins to other bodily areas, causing other diseases (Pollock, 2014, p. 89-98). As a treatment, Rosenow advised the surgical removal of the 'loci of infection' (Rosenow, 1916, p. 359). However, the focal infection theory kept on drawing increasing criticism. It soon became evident that it is both life-threatening and practically impossible to try to remove all the loci of infection, and that one can have focal sepsis and still lead a perfectly healthy life (Pollock, 2014, p. 92). Eventually, by 1940 Rosenow's theory was flatly rejected by Grossman (1940). Because of a misconceived mechanism for infection and unviable treatment, this strand of bacterial research faded away well before Palmer's study.

Altogether, the significance of microbes in the stomach was not appreciated (Pollock, 2014, p. 89). Contemporary researchers regarded bacterial presence as 'accidental' or at best secondary, following the ulceration but not causing it (Dragstedt, 1917; Henry, 1942; Hinton, 1936; Smithies, 1935; Winkelstein, 1936). This pattern continued outside of the US, as the presence of bacteria in the stomach kept being reported after the war (Barber and Franklin, 1946; Cregan, Dunlop, and Hayward, 1953) and even after Palmer's paper (Bishop and Anderson, 1960; Franklin and Skoryna, 1966). Nevertheless, in each case the researchers did not assign any etiological role to the found microorganisms and maintained their beliefs that healthy stomachs are sterile.

An exception was the research by Freedberg and Barron, 1940, who identified spiral bacteria in patients suffering from PUD. However, their study was small in scale and the results inconclusive. As Šešelja and Straßer, 2014b argue, their findings increased the promising character of the bacterial research program, but hardly anyone followed this path. ${ }^{7}$

\footnotetext{
${ }^{7} \mathrm{~A}$ particularly interesting aspect of Freedberg and Barron's study is that they explicitly advice against the employment of hematoxylin-eosin staining technique (later on used by Palmer) for the identification of bacteria, since in contrast to silver staining (subsequently used by Warren and Marshall), it did not reveal the spiral bacteria (see also Šešelja and Straßer, 2014b, Section 5).
} 
Psychogenic Factors Finally, the idea that gastric problems were in some way related to mental activity was a dominant theme in the North American and British literature on indigestion for centuries (Miller, 2010, footnote 30 ). This conjecture had a fertile ground to grow at the beginning of the $19^{\text {th }}$ century, which marked the shift in medicinal practice towards a holistic approach, taking into account not only physical symptoms, but also the psyche, emotions and social environment of a patient (Spiro, 1998, p. 645, Miller, 2011, Ch. 5). The role of psychogenic factors was further corroborated by emerging physiological evidence linking brain malfunction and stomach disturbances (Miller, 2010, p. 101).

Another important development during this time was the rise in influence of Franz Alexander who in 1934 offered a psychogenic hypothesis of ulcer (Spiro, 1998, p. 645, Miller, 2010, p. 101). According to Alexander (1934), ulcer was developed as the result of suppressed subconscious tendencies, such as a desire to be fed, which in turn would trigger a negative somatic response leading to a disease. Furthermore, Robinson (1935) argued that PUD was found only among slender people of white race who as a result of their body type were supposed to have a disposition for mental instability, thus being at risk of developing ulcer. Inspired by these ideas, Davies and Wilson, 1937 proposed the existence of an "ulcer type" of a person. Their work became highly influential and started a quest to define the "peptic ulcer personality" (Miller, 2011, p. 111-113). As Davey Smith (2005) argues, it was the belief in the ulcer-inducing power of stress that shifted the attention away from bacteriological research:

[T]he stress model served to block people from building on this [bacterial theory] and moving towards an answer ... Things may appear clear with hindsight, but people really were directed away from a treatment for peptic ulcers that worked - antibiotics - to ones that did not.

Coincidentally, the outbreak of the WWII also boosted the influence of the psychogenic theory (Christie and Tansey, 2002, p. i). The incidence of peptic ulcer grew at an unprecedented rate, especially among troops internationally, and stomach disorders quickly became a major health complaint (Miller, 2010, p. 97). The war and the ulcers were associated so strongly that already early into the war, British practitioners began calling PUD a "military dyspepsia' or a "war ulcer". This novel rate of increase in ulcers was a new phenomenon and defied any logic in medical thinking. First, it contrasted with the First World War, during which abdominal problems went relatively unnoticed (ibid., p. 97). Secondly, on the Eastern Front, few 
soldiers on the front-line developed ulcers, as opposed to those further back in the supply line (Miller, 2010, p. 97). Some researchers associated peptic ulcers with poor nutrition in the war-zone (Hoelzel, 1943; Steele, 1944), but even as diet improved, the rate of occurrence kept increasing, reaching its peak in the mid-1950s (Jones, 2012, p. 1). As a result, in these post-Freudian days of the 1950s the psychosomatic factors, especially stress, in combination with "ulcer type personality", were widely thought to be the main cause of the ulcer (Christie and Tansey, 2002, p. i). Looking for a connection between the army service and PUD continued in the US after the war and became a focus of several studies (Barrett, 1953; Garbat, 1946; Halsted and Weinberg, 1946; Palmer and Sullivan, 1952).

In this section we have provided an overview of developments other than Palmer's paper, which contributed to the demise of the bacterial theory of the PUD etiology. This summary aimed to be primarily descriptive (rather than normative): while we presented a number of potentially relevant factors in the abandonment of the bacterial theory, we did not evaluate whether such a neglect was epistemically warranted (we will come back to this point in Section 4). Moreover, we do not claim we have established a definite answer as to what put the germ theory to a pause. However, we hoped to have shown that there was a variety of factors that worked against it. In the next section, we will put forward a thesis that by the time Palmer's infamous study was published, the germ theory had already been marginalized and cast aside by the overwhelming majority of scientists.

\section{The status of bacterial research program prior to Palmer's study: digital textual analysis}

In this section we examine the following historical inquiry: to what extent was the bacterial hypothesis of PUD pursued prior to the publication of Palmer's 1954 study? In other words, did the bacterial hypothesis of PUD belong to a declining research program prior to the publication of Palmer's results? By answering this question we will be in a better position to judge the significance of Palmer's result on the abandonment of the bacterial hypothesis.

The motivation for asking this question comes from a few separate considerations. First, as we have seen in the previous section, towards the 1950s, 
the overall research climate was not very forthcoming to the bacterial hypothesis. Second, assuming that the bacterial research program was active in the early 1950s, it is surprising that nobody noticed the methodological error underlying Palmer's results. Finally, looking at the articles on the etiology of PUD published in the early 1950s, one can easily encounter articles that do not even mention bacteria as a potentially relevant factor (as noted by Šešelja and Straßer, 2014b). Nevertheless, these indicators are insufficient evidential basis for answering the above query, whether Palmer's paper was indeed a game-changer to PUD researchers. To approach the issue more systematically we turn to digital textual analysis of the relevant literature.

\subsection{Methodology}

To address the above historical question, we have performed a digital textual analysis of a selection of English language articles published in the period from 1943-1953 ${ }^{8}$. More precisely, we have selected articles in PubMED database that have a MeSH Major Topic "Peptic Ulcer/etiology". We have opted for this term under the assumption that it would pick out the articles that are most likely to feature any significant research on bacteria as an etiological factor in PUD. ${ }^{10}$ Our search resulted in 186 hits, but actually consisting of 184 unique and complete papers, out of which we have managed to access 163 manuscripts. ${ }^{11}$

All the manuscripts have been digitally processed via the Optical Character Recognition software (OCR). To determine the presence of the bacterial research program in this body of manuscripts, we have examined the

\footnotetext{
${ }^{8}$ The textual analysis did not consider books published during this period. These resources could be included in futures studies.

${ }^{9}$ Medical Subject Headings (MeSH) terms are assigned to articles by the U.S. National Library of Medicine. MeSH Major Topic stands for the main topic of the given article, usually obtained from the title and/or statement of purpose (see https://www.nlm.nih.gov/ bsd/disted/meshtutorial/principlesofmedlinesubjectindexing/majortopics/ accessed on July 14, 2019). Our complete search term was: "Peptic Ulcer/etiology"[MAJR] AND

(("1943/01/01"[PDAT] : "1953/12/31"[PDAT]) AND English[lang]).

${ }^{10} \mathrm{MeSH}$ terms are either assigned to articles by human reviewers or automatically using natural language processing methods. In our case 80 out of 186 positions have been indexed automatically (without human supervision), making it not implausible that some "germ theory" articles were omitted. Whether it indeed was the case is not practically feasible for us to either confirm or reject, though.

${ }^{11}$ A paper by Monro (1948) was published twice, while a paper by Chattopadhyaya (1951) was split in two. The main reason we couldn't retrieve all the articles is that they are not available in libraries across Germany, which means that obtaining them would be significantly more costly.
} 
number of occurrences of the following strings: 'bacter*' and 'spiroch*' standing for all the words starting with 'bacter'/'spiroch' (such as bacteria/spirochetes ${ }^{12}$ ). To digitally analyze the text in this way we have used pdfgrep, an open source Linux command line tool for searching text in PDF files (see https://pdfgrep.org/). More precisely, we have used the following command: pdfgrep -R - c "string", which displays the number of instances of the given string in each file within the given folder. For each occurrence of the string, we have first-hand examined the context in which the string appears in order to determine whether the term is related to the bacterial hypothesis of PUD. In addition, for the sake of comparison, we have searched for the number of occurrences of the strings related to keywords of the acidity hypothesis, such as 'acid*'.

\subsection{Results}

Among the analyzed manuscripts, we have found hardly any occurrence of the string 'bacter*', and no occurrence of the string 'spiroch*'. Out of 163 analyzed papers, only four mention bacteria as a possible cause of PUD. Out of these four papers, only one mentions bacteria in a more detailed context (Barber and Franklin, 1946), while the remaining three list it as one of numerous possible etiological factors (see Table 1). In contrast, string 'acid*' appears in 145 of the analyzed manuscripts.

The average occurrence of string 'bacter*' in the whole set of examined articles is 0.41 times per article, while the average occurrence of string 'acid*' is 14.58 times per article. Such a low average of bacteria-related strings, coupled with roughly a 30-fold disparity in the frequency of occurrence, is indicative of the declining status of the germ research program.

\subsection{Discussion}

These results suggest that the bacterial hypothesis was indeed a declining research program already before the publication of Palmer's study, at least in the gastroenterological journal literature in English language.

We have further corroborated these findings by the following data. Table 2 shows the number of articles appearing for the given search terms (of all types, including MeSH terms) in PubMed, published in English language from 1943-1953:

\footnotetext{
${ }^{12}$ Spirochetes are spiral bacteria discussed by Palmer and others (e.g. by Freedberg and Barron, see Section 2) in the context of PUD.
} 


\begin{tabular}{l|l} 
Article & $\begin{array}{l}\text { The context in which bacteria are mentioned } \\
1946\end{array}$ \\
Lust, 1952 & $\begin{array}{l}\text { Bacterial hypothesis is taken seriously and pre- } \\
\text { vious studies mentioned; the main purpose of } \\
\text { the study is determining the presence of bacte- } \\
\text { ria in the stomach and duodenum at the time of } \\
\text { operation. } \\
\text { A book review: bacteria (from food and phar- } \\
\text { maceuticals) are mentioned as one of the causes } \\
\text { of mucosal damages causing gastro-duodenitis, } \\
\text { which in turn causes PUD; this inflammatory } \\
\text { process is considered unrelated to the secretion } \\
\text { of the stomach. } \\
\text { Bacteria are mentioned as one of nine possible } \\
\text { etiological factors of PUD, discussed by a previ- } \\
\text { ous study. } \\
\text { Bacterial infection mentioned as one of the many } \\
\text { possible "extrinsic factors" that has been inves- } \\
\text { tigated in the context of PUD. }\end{array}$
\end{tabular}

Table 1: Articles extracted via our search, which mention bacteria as an etiological factor in PUD. 


\begin{tabular}{lr} 
Search terms & Number of articles \\
\hline 'peptic ulcer' AND 'bacter*, & 8 \\
'peptic ulcer' AND 'spiroch*, & 0 \\
'peptic ulcer' AND 'bacil*' & 0 \\
'peptic ulcer' AND 'antibiotic*, & 3 \\
'peptic ulcer' AND 'urea*', & 2 \\
'peptic ulcer' AND 'pepsin*, & 10 \\
'peptic ulcer' AND 'acid*' & 69 \\
'peptic ulcer' AND 'vagus' & 135 \\
'peptic ulcer' AND 'vagotomy' & 238 \\
'peptic ulcer' AND 'surg*' & 879 \\
'peptic ulcer' AND 'treatment' & 1,130 \\
'peptic ulcer' & 2,659
\end{tabular}

Table 2: Results of the search in PubMed for the time period 1943-1953, for publications in English language. The search terms were chosen at our discretion but we tried to minimize the author bias by including multiple diverse terms. The results for each search do not exclude the remaining strings, and hence, the same paper may be counted towards different search results.

The number of hits for the acidity research program ('acid*', 'vagus', 'vagotomy') is again much higher than the number of hits for the bacterial research program. ${ }^{13}$

\section{Declining research programs as a philosophical problem}

As mentioned in the previous section, our results provide evidence for the claim that bacterial research program was largely abandoned already before 1954, the year when Palmer published his paper. Hence, it is not surprising

\footnotetext{
${ }^{13}$ Concerning the 8 articles appearing in the search, not all of them belong to the bacterial research program either (e.g. some are related to infections resulting from a perforated ulcer, bacterial diseases that are complicated by the appearance of peptic ulcers, or the reduction of acidity in the stomach via substances of bacterial origin.) We list the number of hits for 'peptic ulcer' alone mainly to show the overall number of papers in this research area at the time. Almost half of these are on various approaches to the treatment of the disease. It is also worth mentioning that the number of articles on peptic ulcer available in the database is biased towards the 1950s: out of 2,659 hits for 'peptic ulcer' more than half are from 1950-1953.
} 
that the bacterial hypothesis got dropped after Palmer's publication: it simply belonged to a declining research program. At the same time, it seems unlikely that the bacterial program was dropped because of Palmer's study. If anything, the latter may have just assured scientists that the contemporary research community did not miss much by dropping this line of inquiry.

However, the above conclusion opens a new set of philosophical questions. In particular, this case-study reveals the importance of what we have defined as declining research programs. In contrast to Lakatos's notion of degenerating research programs, which is normative in character, ${ }^{14}$ our term is descriptive. It aims to capture the factual issue of whether and to which extent a given research program is pursed by the relevant scientific community at a certain point in time, irrespective of whether such a development is epistemically warranted or not. In other words, a declining research program may be an inquiry that has lost popularity for a variety of reasons. Its decline (and eventual abandonment) may be epistemically and heuristically justified or unjustified; it may be planned and intentional or simply coincidental.

Now, a particularly interesting type of declining research programs are those whose abandonment is epistemically and heuristically unjustified, in the sense that there were no good epistemic and heuristic reasons for their abandonment. ${ }^{15}$ Put differently, these would be theoretical units that are judged as worthy of pursuit, in view of information available at the time, but which failed to be actively pursued.

While there are different criterial accounts of pursuit-worthiness of scientific theories (e.g. Whitt, 1992, Šešelja and Straßer, 2014a), they mainly come down to the question: does the given research line allow for open lines of inquiry that are promising of increasing explanatory and/or predictive power of our theories in the given domain, and are there methodologically feasible ways to proceed further in spite of current problems (such as counter-evidence, explanatory anomalies etc.) and towards their resolution? Inquiries that are worthy of pursuit are thus such that abandoning them could potentially lead to a major epistemic harm, such as a failure to efficiently achieve the goals of scientific inquiry. As a result, identifying

\footnotetext{
${ }^{14}$ For instance, according to Lakatos "in a progressive research programme, theory leads to the discovery of hitherto unknown novel facts. In degenerating programmes, however, theories are fabricated only in order to accommodate known facts." (Lakatos, 1978, p. 5).

${ }^{15}$ By epistemic reasons we mean considerations pertaining to the knowledge claims made by scientists, such as the increase in cognitive values that apply to them (explanatory and predictive power, consistency, etc.) in view of the relevant evidence (see Šešelja, Kosolosky, and Straßer, 2012). By heuristic reasons we mean a broader set of methodological considerations, which show that the given inquiry is generally feasible (see Nickles, 2006).
} 
a declining research program which is at the same time worthy of pursuit points to a problem in the given scientific domain.

Of course, such a decline may result from a biased view in the given scientific community, dogmatic towards a novel proposal. ${ }^{16}$ However, this may not necessarily be the case. A research program, which is worthy of pursuit, can become declining also coincidentally, for example, due to the relevant scientists having retired or having moved onto other inquiries. Such a scenario may point to a structural problem in the given scientific community, which has failed to enforce a sufficiently rich division of cognitive labor. As frequently noted by pluralists in philosophy of science (e.g. Longino, 2002, Chang, 2012), due to uncertainty that is integral to scientific inquiry, it is important to hedge our bets on multiple research lines. Therefore, observing a declining research program, which is deemed worthy of pursuit can be a symptom of an organizational failure in the given scientific community.

Going back to the case of PUD, it has previously been argued that the bacterial theory of PUD was worthy of pursuit in the 1950s, even after the publication of Palmer's results (Šešelja and Straßer, 2014b). As the authors argue, the bacterial theory not only had open lines of inquiry, but for each of the major objections directed against it, there were clear methodological responses available at the time. ${ }^{17}$ If we agree with this assessment, then in view of the results presented in the current paper the bacterial line of inquiry appears to be a declining research program which was in fact worthy of pursuit. But if Palmer's study wasn't the key factor in such a decline, we are confronted with the question: who (if anyone) is to be held responsible for the abandonment of the bacterial research program? This is an interesting philosophical puzzle, which has inspired accounts of collective epistemic responsibility (such as Fleisher and Šešelja, 2019) and which requires further historical research to be properly addressed.

Perhaps even more importantly, recognizing declining research programs that are worthy of pursuit may be an important socio-epistemological tool in philosophical discussions of contemporary scientific practice. By identifying such instances we may spot missed opportunities and threats of epistemic harm.

\footnotetext{
${ }^{16}$ As argued by Šešelja and Weber, 2012 this is what happened with the research line following Wegener's hypothesis of continental drift, which had a growth (or a 'progressive problem-shift') throughout the $1920 \mathrm{~s}$, but was largely rejected as not even worthy of pursuit by some North American scientists in the 1930s (see also Oreskes, 1999).

${ }^{17}$ Beside the objection coming from Palmer's study, Šešelja and Straßer also examine the objection that the bacteria cannot survive in the acid environment of the stomach, as well as the objections coming from the successes of the acidity research line.
} 


\section{Conclusion}

In this paper we have re-examined the history of the research on PUD, and the role of Palmer's infamous study, which has long been considered a gamechanger that convinced other scientists bacteria cannot be an etiological factor in this disease. To this end, we have used digital tools to systematically analyze a scope of journal articles published in English language in the decade before Palmer's publication. Our results suggest that the bacterial hypothesis belonged to a declining research program already before Palmer's publication. This would indicate that the impact of a single influential figure on the whole research program is perhaps overestimated in the received view. Our study raises a number of questions concerning this episode, which future research may help to answer. For instance, we have assumed throughout the paper that the bacterial research program was as popular as the acidity one at the beginning of the twentieth century. It would, however, be interesting to conduct a more detailed analysis of the literature in this time period and reexamine the state of affairs. Moreover, the status of the bacterial hypothesis in non-English speaking literature is another open question worthy of further investigation.

We will close by highlighting two main take-home messages from our study. First, our discussion indicates the importance of the notion of a declining research program as a philosophical tool that, in combination with normative assessments, can aid in revealing potential problems in the organizational structure of a given scientific community. While the PUD case may not be a suitable example of a situation in which misleading information spreads quickly throughout a given scientific community (as suggested by Zollman, 2010), ${ }^{18}$ it is still an example of a harmful loss of research diversity, or Zollman's 'transient diversity'. Similarly, it is also an example supporting Kummerfeld and Zollman's (2016) argument for an organized division of cognitive labor (e.g. in the form of institutional control), in contrast to the view that the 'scientific state of nature' (i.e. a state in which scientists are left to make their own decisions on what they should pursue) allows for an optimal scientific enterprise. ${ }^{19}$

\footnotetext{
${ }^{18} \mathrm{We}$ are not suggesting that the scientific community at the time was not tightly connected, but rather, that factors other than the connectedness of the community and the structure of its information flow may be more explanatory of the development of the episode.

${ }^{19}$ The scientific state of nature, or the 'autonomist' view of scientists is perhaps most prominently featured in the work of Polanyi, 1951. For different approaches to the opposite view see e.g. Kitcher's (2011) 'well-ordered science' or Shaw's (2018) proposal based on Fayerabend's pluralism and Peirce's economics of theory pursuit.
} 
Second, the availability of digital tools makes reexaminations of historical episodes discussed by philosophers of science timely and relevant. In addition to the method of textual analysis employed in this paper, other types of related methods may be even more suitable for similar investigations. In particular, citation analysis in view of bibliometric data may provide insights into social networks characteristic of the scientific community at the time. ${ }^{20}$ The reason we have turned to textual analysis rather than to the citation analysis is that the bibliometric data for this time period is rather sparse. Hence, obtaining reliable data (e.g. on how many scientists cited Palmer's paper) proved difficult. However, for more recent case-studies, bibliometric data may be a valuable additional evidence.

Acknowledgments We are grateful to the RTG Situated Cognition at Ruhr University Bochum and to Christian Straßer for valuable comments on an earlier draft of this paper. The research for this paper was partially funded by the Munich Center for Mathematical Philosophy (MCMP) at LMU Munich and the DFG (Research Grant HA 3000/9-1).

\section{References}

Ætiology of Peptic Ulcer (1949). "Ætiology of Peptic Ulcer. Editorial". In: The Lancet 254.6587, pp. 997-998. ISSN: 0140-6736. DOI: https://doi.org/ 10.1016/S0140-6736(49) 91564-0. URL: http: //www. sciencedirect. com/science/article/pii/S0140673649915640.

Alexander, Franz (1934). "The Influence of Psychologic Factors Upon GastroIntestinal Disturbances: A Symposium". In: The Psychoanalytic Quarterly 3.4, pp. 501-539. ISSN: 0033-2828. DOI: 10.1080/21674086.1934. 11925219. URL: https://doi.org/10.1080/21674086.1934.11925219.

Arends, Norman W. (1951). "Symposium on peptic ulcer anatomy and pathologic physiology." In: The Journal of the American Osteopathic Association 51.2, pp. 112-114.

Barber, Mary and R H Franklin (1946). "Bacteriology of Peptic Ulcer and Gastric Carcinoma". In: British Medical Journal 1.4459, pp. 951-953. ISSN: 0007-1447. URL: http://www.ncbi.nlm.nih.gov/pmc/articles/ PMC2059256/.

\footnotetext{
${ }^{20}$ For examples of using social network analysis in the context of integrated history and philosophy of science see Claveau and Herfeld, 2018, Catherine and Doehne, 2018. For a more general discussion on digital approaches to philosophy of science see Pence and Ramsey, 2018.
} 
Barrett, A A (1953). "Duodenal ulcer in military personnel: a social service study of 40 cases." eng. In: United States Armed Forces medical journal 4.12, pp. 1693-1702. ISSN: 0566-0777 (Print).

Bishop, Ruth F. and Charlotte M. Anderson (1960). "The bacterial flora of the stomach and small intestine in children with intestinal obstruction". In: Archives of Disease in Childhood 35.183, pp. 487-491. ISSN: 00039888. DOI: $10.1136 /$ adc.35.183.487. URL: http://www.ncbi.nlm.nih.gov/ pmc/articles/PMC2012577/.

Bralow, S P, M A Spellberg, H Kroll, and H Necheles (1950). "Peptic ulcer in man. Part I. The ulcer problem". In: The American Journal of Digestive Diseases 17.2, pp. 41-45. ISSN: 1573-2568. DOI: $10.1007 /$ BF03002510. URL: https://doi.org/10.1007/BF03002510.

Carter, Kay Codell (2003). The rise of causal concepts of disease: Case histories. Ashgate Publishing, Ltd.

Catherine, Herfeld and Malte Doehne (2018). "Five reasons for the use of network analysis in the history of economics". In: Journal of Economic Methodology 25.4, pp. 311-328.

Chang, Hasok (2012). Is Water H2O? Evidence, Pluralism and Realism. Springer.

Christie, D A and E M Tansey, eds. (2002). Peptic Ulcer: Rise and Fall. Vol. 14. Wellcome Witnesses to Twentieth Century Medicine. London: Wellcome Trust Centre for the History of Medicine at UCL.

Claveau, François and Catherine Sophia Herfeld (2018). "Social network analysis: A complementary method of discovery for the history of economics". In: Forthcoming, A Contemporary Historiography of Economics, E. Roy Weintraub and Till Düppe (eds.), Routledge.

Connell, F Gregory (1949). "Trends in diagnosis, etiology and treatment of duodenal ulcer". In: The American Journal of Digestive Diseases 16.2, pp. 55-63. ISSN: 1573-2568. DOI: 10 . 1007 /BF03001878. URL: https : //doi.org/10.1007/BF03001878.

Cornell, Beaumont S, Franz J Lust, and James L Wyatt (1944). "Editorial". In: The American Journal of Digestive Diseases 11.1, pp. 20-23. ISSN: 1573-2568. DOI: 10 . 1007 / BF03003247. URL: https : / / doi . org/ 10 . $1007 / \mathrm{BF} 03003247$.

Cregan, Judith, E E Dunlop, and Nancy J Hayward (1953). "Bacterial Content of Human Small Intestine in Disease of the Stomach". In: British Medical Journal 2.4848, pp. 1248-1251. ISSN: 0007-1447. URL: http : //www.ncbi.nlm.nih.gov/pmc/articles/PMC2030253/.

Davey Smith, G (2005). "The biopsychosocial approach: a note of caution". English. In: Biopsychosocial Medicine: An Integrated Approach To Un- 
derstanding Illness. New York, NY: Oxford University Press, pp. 77-102. ISBN: 9780198530343 . DOI: 10 .1093/med : psych/9780198530343.003. 0005. URL: https://www . oxfordclinicalpsych.com/view/10.1093/ med : psych/9780198530343.001.0001/med-9780198530343-chapter5.

Davies, Daniel T. and Alexander T. M. Wilson (1937). "Observations on the life-history of chronic peptic ulcer". In: The Lancet 230.5963, pp. 13531360. ISSN: 0140-6736. DOI: 10 . 1016/S0140-6736(00) 88967-9. URL: http://dx.doi.org/10.1016/S0140-6736(00)88967-9.

Dragstedt, L R (Oct. 1935). "Some Physiologic Principles Involved In the Surgical Treatment of Gastric and Duodenal Ulcer". In: Annals of surgery 102.4, pp. 563-580. ISSN: 0003-4932.

Dragstedt, Lester R. (Feb. 1917). "Contributions to the physiology of the stomach: Xxxviii. gastric juice in duodenal and gastric ulcers". In: Journal of the American Medical Association LXVIII.5, pp. 330-333. ISSN: 00029955. URL: http://dx.doi.org/10.1001/jama.1917.04270020010003.

Dragstedt, Lester R (1945). "Vagotomy for Gastroduodenal Ulcer ". In: Annals of Surgery 122.6, pp. 973-989. ISSN: 0003-4932. URL: http://www. ncbi.nlm.nih.gov/pmc/articles/PMC1618352/.

Dragstedt, Lester R, Edward H Camp, and James M Fritz (1949). "Recurrence of Gastric Ulcer after Complete Vagotomy". In: Annals of Surgery 130.4, pp. 843-854. ISSN: 0003-4932. URL: http://www.ncbi.nlm.nih. gov/pmc/articles/PMC1616440/.

Dragstedt, Lester R, Paul V Harper, E Bruce Tovee, and Edward R Woodward (1947). "Section of the Vagus Nerves to the Stomach in the Treatment of Peptic Ulcer : Complications and End Results After Four Years". In: Annals of Surgery 126.5, pp. 687-699. ISSN: 0003-4932. URL: http: //www.ncbi.nlm.nih.gov/pmc/articles/PMC1803514/.

Dragstedt, Lester $\mathrm{R}$ and Frederick M Owens (June 1943). "SupraDiaphragmatic Section of the Vagus Nerves in Treatment of Duodenal Ulcer." In: Proceedings of the Society for Experimental Biology and Medicine 53.2, pp. 152-154. ISSN: 0037-9727. DOI: 10.3181/00379727-53-14227. URL: http : / / journals . sagepub . com/doi/abs/10 . 3181/00379727 53-14227.

"Editorial" (1954a). In: The American Journal of Digestive Diseases 21.8, p. 240. ISSN: 1573-2568. DOI: 10.1007/BF02881373. URL: https://doi. org/10.1007/BF02881373.

"Editorial" (1954b). In: The American Journal of Digestive Diseases 21.5, p. 145. ISSN: 1573-2568. DOI: 10.1007/BF02897189. URL: https://doi. org/10.1007/BF02897189. 
Edwards, Leonard W, William H Edwards, John L Sawyers, Walter G Gobbel Jr, J Lynwood Herrington Jr, and H William Scott Jr (1963). "The surgical treatment of duodenal ulcer by vagotomy and antral resection". In: The American Journal of Surgery 105.3, pp. 352-360.

Fleisher, Will and Dunja Šešelja (2019). "Collective Epistemic Responsibility: a Preventionist Account". In: Forthcoming. URL: http://philsciarchive . pitt . edu/17003/1/Fleisher_Seselja_Collective - epresp.pdf.

Franklin, Maxine A and Stanley C Skoryna (1966). "Studies on Natural Gastric Flora: I. Bacterial Flora of Fasting Human Subjects". In: Canadian Medical Association Journal 95.26, pp. 1349-1355. ISSN: 0008-4409. URL: http://www.ncbi.nlm.nih.gov/pmc/articles/PMC1935882/.

Freedberg, A. Stone and Louis E. Barron (1940). "The presence of spirochetes in human gastric mucosa". In: American Journal of Digestive Diseases 7.10, pp. 443-445.

Fukuda, Yoshihiro, Tadashi Shimoyama, Takashi Shimoyama, and Barry J. Marshall (2002). "Kasai, Kobayashi and Koch's postulates in the history of Helicobacter pylori". In: Helicobacter pioneers: firsthand accounts from the scientists who discovered helicobacters, 1892-1982. Blackwell Science Asia, pp. 15-24.

Garbat, A.L. (1946). "Problems of peptic ulcer in the armed forces and in the returned soldiers." eng. In: New York state journal of medicine 46, pp. 894-901. ISSN: 0028-7628 (Print).

Gilbert, Margaret (2000). Sociality and responsibility: New essays in plural subject theory. Rowman \& Littlefield.

Grossman, Louis Irwin (1940). Root canal therapy. English. Philadelphia: Lea \& Febiger.

Halsted, J. A. and H. Weinberg (1946). "Peptic ulcer among soldiers in the Mediterranean theater of operations." eng. In: The New England journal of medicine 234, pp. 313-320. ISSN: 0028-4793 (Print).

Henry, C.M. (1942). "Peritoneal fluid and gastric contents in cases of perforated peptic ulcer". In: Archives of Surgery 45.4, pp. 564-570. DOI: 10.1001/archsurg. 1942.01220040060007. eprint: /data/ journals / surg/14484/archsurg_45_4_007.pdf. URL: +http://dx.doi.org/10. 1001/archsurg.1942.01220040060007.

Hinton, J William (1936). "A review of 746 gastric and duodenal ulcers". In: The American Journal of Digestive Diseases 3.1, pp. 59-62. ISSN: 15732568. DOI: 10 . 1007 / BF02999055. URL: https : / / doi . org/10 . 1007 / BF02999055. 
Hobsley, M (1994). "Dragstedt, gastric acid and duodenal ulcer." In: The Yale Journal of Biology and Medicine 67.3-4, pp. 173-180. ISSN: 0044-0086. URL: http://www.ncbi.nlm.nih.gov/pmc/articles/PMC2588933/.

Hoelzel, Frederick (1943). "Nutritional versus psychic factors in peptic ulcer". In: The American Journal of Digestive Diseases 10.6, pp. 239-240. ISSN: 1573-2568. DOI: 10 . 1007 / BF02998041. URL: https : / / doi . org / 10 . $1007 / \mathrm{BF} 02998041$.

Ivy, A C (1950). Peptic ulcer. Philadelphia. URL: file : / / catalog . hathitrust . org/Record/001583831http : / / hdl . handle . net/2027 / osu. 32436000490035.

Jones, Edgar (2012). "The gut war': Functional somatic disorders in the UK during the Second World War". In: History of the human sciences 25.5, pp. 30-48. ISSN: 0952-6951. DOI: 10.1177/0952695112466515. URL: http://www.ncbi.nlm.nih.gov/pmc/articles/PMC5130149/.

Kidd, Mark and Irvin M Modlin (1998a). "A century of $\{\mathrm{H}\}$ elicobacter pylori". In: Digestion 59.203, pp. 1-15.

- (1998b). "A century of Helicobacter pylori". In: Digestion 59.1, pp. 1-15.

Kirsner, Joseph B. and Walter L. Palmer (1952). "Seminars on gastrointestinal physiology: the problems of peptic ulcer". In: American Journal of Medicine 13.5, pp. 615-639. URL: https : //doi .org/10 .1016/00029343(52) 90028-4.

Kitcher, Philip (2011). Science in a democratic society. Prometheus Books. Kuhn, Thomas (1962 [1996]). Structure of Scientific Revolutions. 3rd ed. Chicago: The University of Chicago Press.

Kummerfeld, Erich and Kevin JS Zollman (2016). "Conservatism and the scientific state of nature". In: The British Journal for the Philosophy of Science 67.4, pp. 1057-1076.

Lakatos, Imre (1978). The methodology of scientific research programmes. Cambridge: Cambridge University Press.

Laudan, Larry (1977). Progress and its Problems: Towards a Theory of Scientific Growth. London: Routledge \& Kegan Paul Ltd.

Longino, Helen (2002). The Fate of Knowledge. Princeton: Princeton University Press.

Lust, Franz J. (1952). "Konjetzny's theory of the development of gastroduodenal ulcer". In: The American journal of digestive diseases 19.6, p. 194.

Marshall, Barry J. (2002). Helicobacter pioneers: firsthand accounts from the scientists who discovered helicobacters, 1892-1982. Blackwell Science Asia. 
Mears, Fredrick B (1953). "Autopsy survey of peptic ulcer associated with other disease: A review of related etiological factors concerned". In: Surgery 34.4, pp. 640-654.

Miller, Boaz (2013). "When is consensus knowledge based? Distinguishing shared knowledge from mere agreement". In: Synthese 190.7, pp. 12931316 .

Miller, I. (2011). A Modern History of the Stomach: Gastric Illness, Medicine and British Society, 1800-1950. Studies for the Society for the Social History of Medicine. Taylor \& Francis. ISBN: 9781317322474 . URL: https : //books.google.co.uk/books?id=fbs6CgAAQBAJ.

Miller, Ian (2010). "The Mind and Stomach at War: Stress and Abdominal Illness in Britain c.1939-1945". In: Medical History 54.1, pp. 95-110. ISSN: 0025-7273. URL: http : / / www . ncbi . nlm . nih . gov/pmc/articles / PMC2793144/.

Nickles, Thomas (2006). "Heuristic Appraisal: Context of Discovery or Justification?" In: Revisiting Discovery and Justification: Historical and philosophical perspectives on the context distinction. Ed. by Jutta Schickore and Friedrich Steinle. Netherlands: Springer, pp. 159-182.

Oreskes, Naomi (1999). The Rejection of Continental Drift: Theory and Method in American Earth Science. New York, Oxford: Oxford University Press.

Palmer, E. D. (1954). "Investigation of the gastric mucosa spirochetes of the human." In: Gastroenterology 27.2, pp. 218-220.

Palmer, E. D. and B. H. Sullivan (1952). "Duodenal ulcer in military personnel; studies on military effectiveness of the ulcer patient: 1 . The problem." eng. In: United States Armed Forces medical journal 3.3, pp. 455-459. ISSN: 0566-0777 (Print).

Pence, Charles H and Grant Ramsey (2018). "How to do digital philosophy of science". In: Philosophy of Science 85.5, pp. 930-941.

"Peptic ulcer and "ordinary" anxiety" (1950). In: The American Journal of Digestive Diseases 17.8, p. 289. ISSN: 1573-2568. DOI: $10.1007 /$ BF03002541. URL: https://doi.org/10.1007/BF03002541.

Polanyi, Michael (1951). The logic of liberty. Routledge.

Pollock, Alexander Chapman (2014). "From dyspepsia to Helicobacter : a history of peptic ulcer disease". Doctoral Thesis. University of Glasgow.

Robinson, Samuel C (1935). "On the etiology of peptic ulcer". In: The American Journal of Digestive Diseases 2.6, pp. 333-343. ISSN: 1573-2568. DOI: 10.1007/BF03000846. URL: https://doi .org/10.1007/BF03000846.

Rosenow, Edward C (1916). "The Causation of Gastric and Duodenal Ulcer by Streptococci: Plates 5 to 14". In: The Journal of Infectious Dis- 
eases 19.3, pp. 333-384. ISSN: 00221899. URL: http://www.jstor.org/ stable/30080335.

Rosenow, Edward C and A H Sanford (1915). "The Bacteriology of Ulcer of the Stomach and Duodenum in Man". In: The Journal of Infectious Diseases 17.1, pp. 219-226. ISSN: 00221899. URL: http://www . jstor. org/stable/30083497.

Rowland, Vernon C (1937). "The etiology of peptic ulcer". In: The American Journal of Digestive Diseases 4.11, pp. 760-762. ISSN: 1573-2568. DOI: 10.1007/BF03000448. URL: https://doi .org/10.1007/BF03000448.

Schwarz, Karl (1910). "Ueber penetrierende Magen- und Jejunalgeschwuere". In: Beitrage zur klinischen Chirurgie 67, pp. 86-128.

Šešelja, Dunja, Laszlo Kosolosky, and Christian Straßer (2012). "Rationality of Scientific Reasoning in the Context of Pursuit: drawing appropriate distinctions". In: Philosophica 86, pp. 51-82.

Šešelja, Dunja and Christian Straßer (2014a). "Epistemic justification in the context of pursuit: a coherentist approach". In: Synthese 191.13, pp. 31113141.

- (2014b). "Heuristic Reevaluation of the Bacterial Hypothesis of Peptic Ulcer Disease in the 1950s". In: Acta Biotheoretica 62, 429-454.

Šešelja, Dunja and Erik Weber (2012). "Rationality and Irrationality in the History of Continental Drift: Was the Hypothesis of Continental Drift Worthy of Pursuit?" In: Studies in History and Philosophy of Science 43, pp. 147-159.

Shaw, Jamie (2018). "Feyerabend's well-ordered science: how an anarchist distributes funds". In: Synthese, pp. 1-31.

Smithies, Frank (1935). "On an adequate conception of the etiology and the significance of peptic ulcer (gastric and duodenal)". In: The American Journal of Digestive Diseases 2.7, pp. 437-440. ISSN: 1573-2568. DOI: 10.1007/BF03000881. URL: https://doi.org/10.1007/BF03000881.

Solomon, Miriam (2001). Social Empiricism. Cambridge, Massachusetts: MIT press.

Spiro, Howard M (1998). "Peptic ulcer: Moynihan's or Marshall's disease?" In: The Lancet 352.9128, pp. 645-646. ISSN: 0140-6736. DOI: https:// doi . org / 10 . 1016 / S0140 - 6736 (97 ) 12058 - X. URL: http : / / www . sciencedirect.com/science/article/pii/S014067369712058X.

Steele, Elizabeth (1944). "Peptic ulcer - suggesting malnutrition as the etiology". In: The American Journal of Digestive Diseases 11.4, pp. 119-122. ISSN: 0002-9211.

Sullivan, A J and Thomas E McKell (1950). Personality in peptic ulcer. Oxford, England: C. C. Thomas, pp. x, 100-x, 100. 
Thagard, Paul (2000). How scientists explain disease. Princeton University Press.

Turck, F B (1907). "FURTHER OBSERVATIONS ON THE ETIOLOGY AND PATHOLOGY OF PEPTIC ULCER." eng. In: British medical journal 1.2416, pp. 922-926. ISSN: 0007-1447 (Print).

- (1908). "Experimental studies on Round Ulcer of the Stomach and Duodenum." eng. In: The Journal of medical research 17.4, pp. 365-378.15. ISSN: 0097-3599 (Print).

Warren, Robin (2005). "Discovery of H. Pylori in Perth, WA". In: Helicobacter pioneers : firsthand accounts from the scientists who discovered helicobacters, 1892-1982. Ed. by Barry J Marshall. Victoria, Australia; Malden, MA, USA: Blackwell, pp. 151-163. ISBN: 0867930357.

Warren, Robin J. and Barry J. Marshall (1983). "Unidentified curved bacilli on gastric epithelium in active chronic gastritis". In: The Lancet 321.8336, pp. $1273-1275$.

Whitt, Laurie Anne (1992). "Indices of Theory Promise". In: Philosophy of Science 59, pp. 612-634.

Winkelstein, Asher (1936). "The etiology and therapy of ulcerative colitis". In: The American Journal of Digestive Diseases 3.11, pp. 839-844. ISSN: 1573-2568. DOI: 10 . 1007 / BF02999280. URL: https : // doi . org/ 10 . 1007/BF02999280.

Wray, K Brad (2010). "Introduction: Collective Knowledge and Science". In: Episteme 7.3, pp. 181-184.

Zollman, Kevin J. S. (2010). "The epistemic benefit of transient diversity". In: Erkenntnis 72.1, pp. 17-35. 